\title{
LATE-QUATERNARY STRATIGRAPHY OF BALTIC SEA BASINS - A REVIEW
}

\author{
BORIS WINTERHALTER
}

\begin{abstract}
WINTERHALTER, BORIS, 1992. Late-Quaternary stratigraphy of Baltic Sea sediments - a review. Bull. Geol. Soc. Finland 64, Part 2, 189-194.

Key words: Marine geology, marine sediments, stratigraphy, deposition, Baltic Sea Stages, Quaternary, Baltic Sea.

Boris Winterhalter: Geological Survey of Finland, SF-02150 Espoo, Finland.
\end{abstract}

\section{Introduction}

The deterioration and the predominantly northnorth-western retreat of the Weichselian (last) ice sheet across the Baltic Sea basin, left behind a variety of glacially sculptured topographic forms on the sea floor. In some areas the original preglacial bedrock morphology was only slightly altered, while, in others, glacially scoured valleys were formed, or large end moraines, longitudinal eskers or even huge drumlins were deposited.

On this irregular substratum late-glacial and postglacial sediments have been deposited in accordance with the prevailing sedimentary regime. The actual sedimentation processes were governed by currents, wave action, and availability of depositional material. The sediments in well-sheltered basins bear a record of all the changes that have occurred in the sedimentary environment from the onset of deglaciation to the present day.

There are four major factors affecting the properties and the stratigraphic characteristics of the Baltic Sea sediments:

1. The regional bedrock of the sea floor and surrounding land areas. The predominantly sedimentary bedrock of the southern and central Baltic Sea and the exposed crystalline basement of the northern parts has influenced both the sediments themselves and the resulting sea floor morphology.

2. Variations in the salinity and other physicochemical parameters together with the actual source of sedimentary material has affected the grain size and mineralogical composition of the deposited material including organic components.

3. Bathymetry and sea floor topography in relation to prevailing barometric (air pressure) and wind fetch conditions together with factors like depth to wave base and the existence of nearbottom currents govern the balance between erosion, non-deposition and sedimentation (Fig. $1)$.

4. Biological factors including bioturbation caused by bottom burrowing animals and decomposition of deposited organic matter.

\section{Sedimentary units}

The proximity of the retreating ice sheet, prevailing climatic conditions, and changes in the water exchange between the Baltic Sea basin and the world ocean, have been key factors governing the deposition of a wide spectrum of sediments, ranging from stony till and various beds of sand, silt and clay to recent gyttja and mud.

Some of the sedimentary units can be traced across most parts of the Baltic Sea area, like those left by the Scandinavian Ice Sheet, while others, e.g. recent gyttja clays or muds, are limited to tranquil sedimentary basins. Some of the units are definitely metachronous, while others can be chronologically correlated (see Fig. 2) 


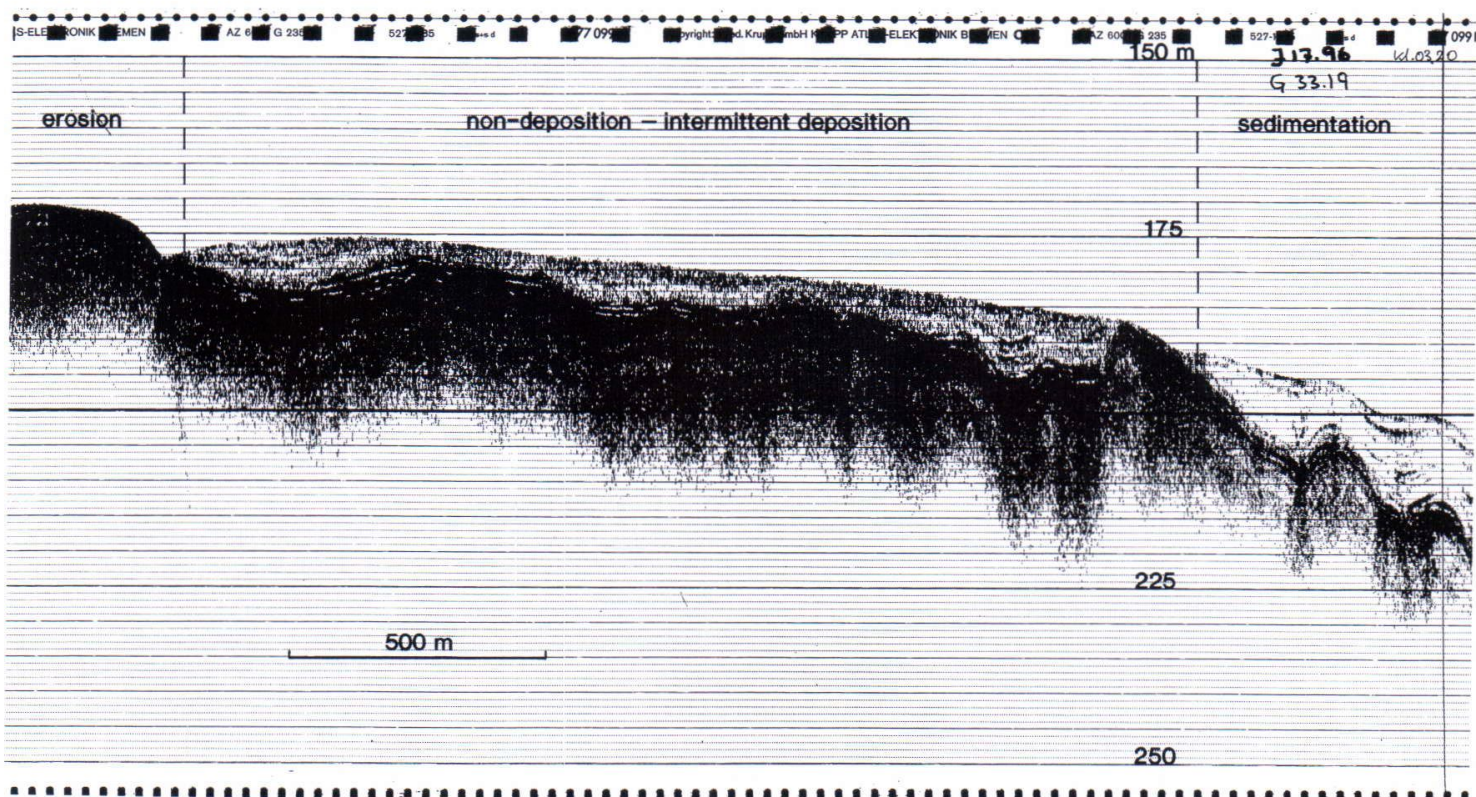

Fig. 1. The echogram from the northeastern Baltic Sea Proper shows a tract of sea bottom where erosion - non-deposition sedimentation prevail at various depths. In the area of erosion (left) late-glacial silty clays are exposed. Non-deposition with possible intermittent deposition and transport of material occurs between depths 175 and 185 meters. Active sedimentation takes place at this site only in depths greater than 190 meters. The underlying bedrock becomes successively older from left (Cambrian) to right (Precambrian).

\section{Glacial drift}

As a rule, the bedrock is covered by glacial till of variable thickness, ranging from a few meters to tens of meters. It may, however, also be completely missing, as in some places within the southwestern Finnish Archipelago Sea. In some areas, large streamlined (drumlinoid) forms (e.g. northern Bothnian Sea, cf. Winterhalter 1972) were deposited. In the Vaasa archipelago, northern Quark, de Geer moraines occur. The material ranges from over-consolidated lodgement till to waterlain tills.

The Younger Dryas ice-marginal formations (Mid-Swedish end moraines and the Salpausselkäridges traversing southern Finland) continue across the northern Baltic Sea proper (e.g. Söderberg, 1988). The material consists primarily of stratified sand and gravel with occasional lenses and interbeds of till.

Vast deposits of sand and gravel are found in the southern Baltic, eastern Gulf of Finland and the Bothnian Bay. Some of these are englacial (longitudinal) accumulations of stratified drift (eskers), while others are deltaic deposits or even beach sands derived from sandy till.

\section{Glacial lacustrine sediments}

The meltwater from the receding ice margin formed a large fresh water lake, the Baltic Ice Lake. The waning ice mass produced enormous quantities of mineral matter, that due to the seasonal character of the melting, were often deposited as annually (rhythmically) varved silty clayey sediments. Variations in varve thickness along the stratigraphic column, can be ascribed to either slight oscillations of the ice margin, local iceberg activity, and most obviously to variations in sediment input by meltwater. 


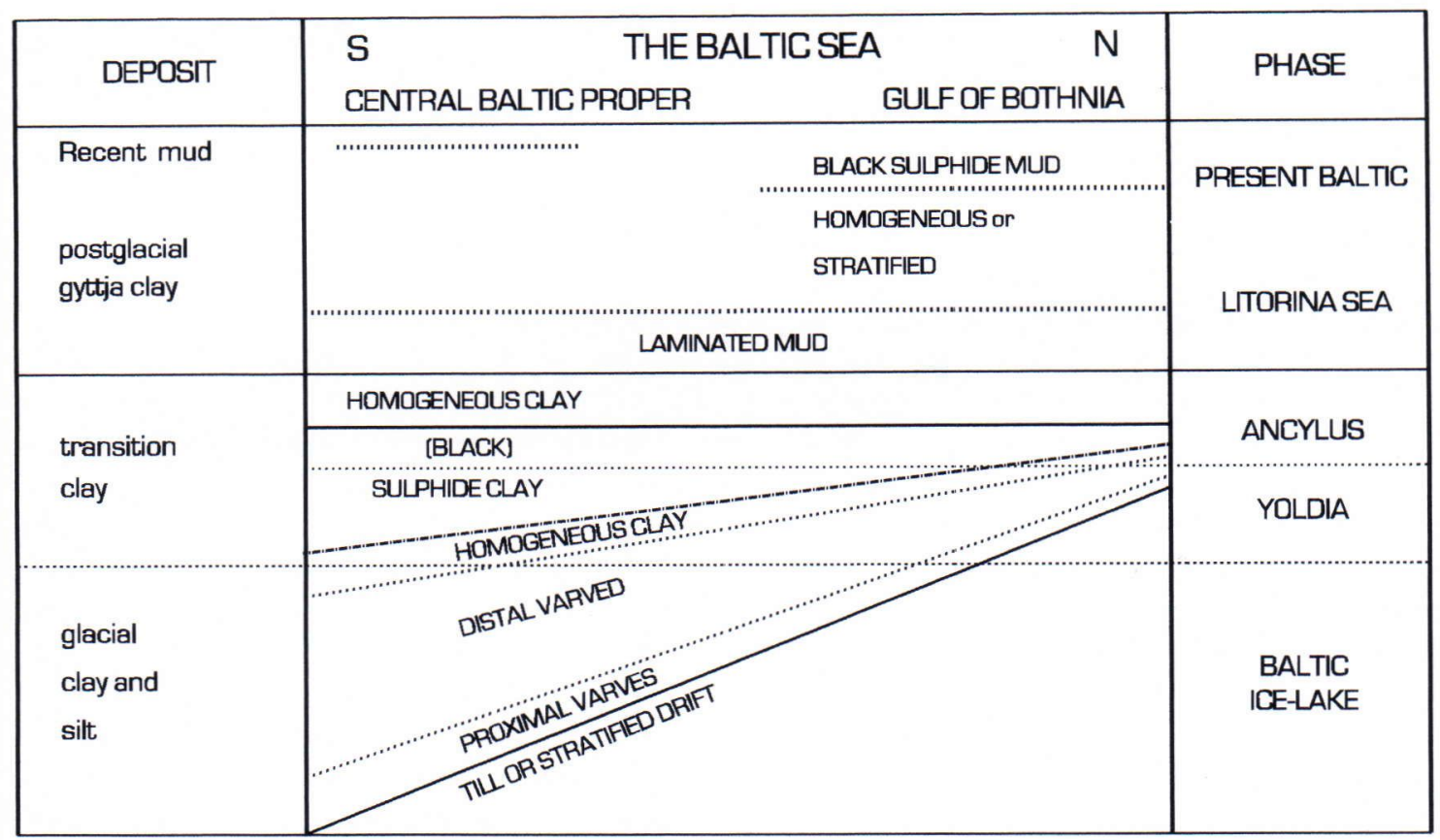

Fig. 2. The schematic graph (modified from Ignatius et al. 1981, Fig. 1.33) shows the time transgressive nature of the lateglacial Quaternary sediments found in deep basins of the Baltic Sea.

The silty varved sediments of the Baltic Ice Lake were, as a rule, deposited conformably on the irregular, glacially sculptured sea bottom. Further away from the ice margin, the proximal varved sediments grade into thinner varved clays (distal varves) and finally into greyish clayey/silty sediments often with brownish lenses and layers (cf. Ignatius 1958). The total thickness of the Baltic Ice Lake sediments is normally several meters (e.g. Gulf of Finland) and often up to ten meters and more especially in the southern parts of the Baltic Sea.

\section{Yoldia sediments}

When the retreating ice margin had reached the relatively low-lying parts of central Sweden, the ice-dammed Baltic Ice Lake drained to world ocean level (e.g. Eronen, 1988). For a short time span, saline waters could flow into the basin giving rise to the Yoldia Sea. Except for the west central parts of the Baltic Sea, the increased salinity has had little effect on the scarce biota of those times. Within the central basins of the Baltic Sea the often weakly banded grey silty clay does exhibit a reddish tint. The sediments themselves do not, however, exhibit any clear lithological boundary that could be ascribed to a marked marine (saline) influence. Thus there has been considerable controversy regarding the exact marine character and extent of this phase especially due to the scarcity of diatoms in the sediments (e.g. Åker et al. 1988)

It should be pointed out that even a slight increase in salinity would most probably have caused density stratification (halocline) of the water masses. This on the other hand could have lead to the development of anoxia in the bottom near waters, thus explaining the observed occurrence of black 
ferrous sulphide (hydrotroilite) staining that abounds in these sediments. The fact remains, that typical varved sediment of the Baltic Ice Lake become higher up along the stratigraphic column predominantly greyish or even bluish in colour with an increasing abundance of black specs, grains and even thin layers of amorphous iron sulphide ( $\mathrm{Pa}-$ punen 1968). Weakly reducing conditions, indicative of density (salinity) stratification, prevailed for a considerable span of time. Whether bottom-near waters had actually been influenced by inflow of oceanic waters (Yoldia marine phase?) across central Sweden is, however, a matter of controversy due to the lack of conclusive evidence of actual marine and not redeposited fossils (e.g. diatoms) in the sediments.

\section{Ancylus Lake sediments}

The upper part of the glacial lacustrine stratigraphic column overlying the silty clay sediments ascribed by some authors to the Yoldia Sea stage, exhibits considerable variations in the magnitude of black ferrous sulphide staining. In the uppermost part the black staining rapidly disappears and the greyish lower Ancylus sediment changes into a homogenous bluish clay. This clear change in sediment character is often accentuated by the occurrence of small dendritic concretions consisting of framboidal pyrite encrusted by lamellar crystals of marcasite (Ignatius et al. 1968). The homogenous bluish clays forming the upper Ancylus deposits are despite their meagre thickness of 0.5 to 1 meters found in most sedimentary basins of the Baltic Sea.

It would seem logical to explain the deposition of the homogenous upper Ancylus clays as a result of a change from stratified water masses to a water basin exhibiting full seasonal mixing. This is probably also related to the diminishing effect of the waning continental ice sheet. Obviously the waters were still heavily laden with clay size mineral particles severely limiting biological productivity due to turbidity.

Finally, due to the eustatic rise of the world oceans, a connection across southwestern Scandinavia (the Danish Straits) is established and saline waters flowed freely into the Baltic Sea.

\section{Litorina Sea deposits}

The inflow of saline water into the rather shallow southern Baltic Sea some 9000 yrs ago and its rapid mixing with the fresh Ancylus Lake waters led to a rapid increase in the over-all salinity. This in turn caused massive flocculation and deposition of suspended mineral particles. Due to the decrease of particulate material in suspension, sunlight could penetrate deeper down (increase in photic layer thickness) resulting in a rapid increase in organic productivity. The abundance of organic matter in conjunction with a marked decrease in fluvial transported mineral matter led to a drastic change in the character of the sediments being deposited (Winterhalter 1972, 1975). The conformable type of sedimentation ascribed to Baltic Ice Lake, Yoldia, and Ancylus deposits changes into a quite different mechanism. Due to the high content of organic matter, the material settling to the bottom, retains a loose texture. Thus even a weak current is capable of resuspending this material and to transport it into deeper areas. The final deposition occurs in sheltered (tranquil) deep basins thus the term »basin fill». These clayey sediments with varying amounts of organic matter can most often be classified as gyttja or gyttja clay.

Occasionally barometric and meteorological conditions are favourable to larger than normal inflow of saline waters through the shallow sills between the World Ocean and the Baltic Sea. In such cases, mixing can be poor and denser water finds its way into basinal parts of the marine area. The large amounts of organic debris settling to the bottom use up the oxygen reserves of the saline bottom waters, finally leading to anoxia and extermination of bottom burrowing fauna. Recolonization can occur only after a new large inflow of saline water. During the anoxic phases well-laminated sediments are formed, differing markedly from the bioturbated sediments formed during oxic 


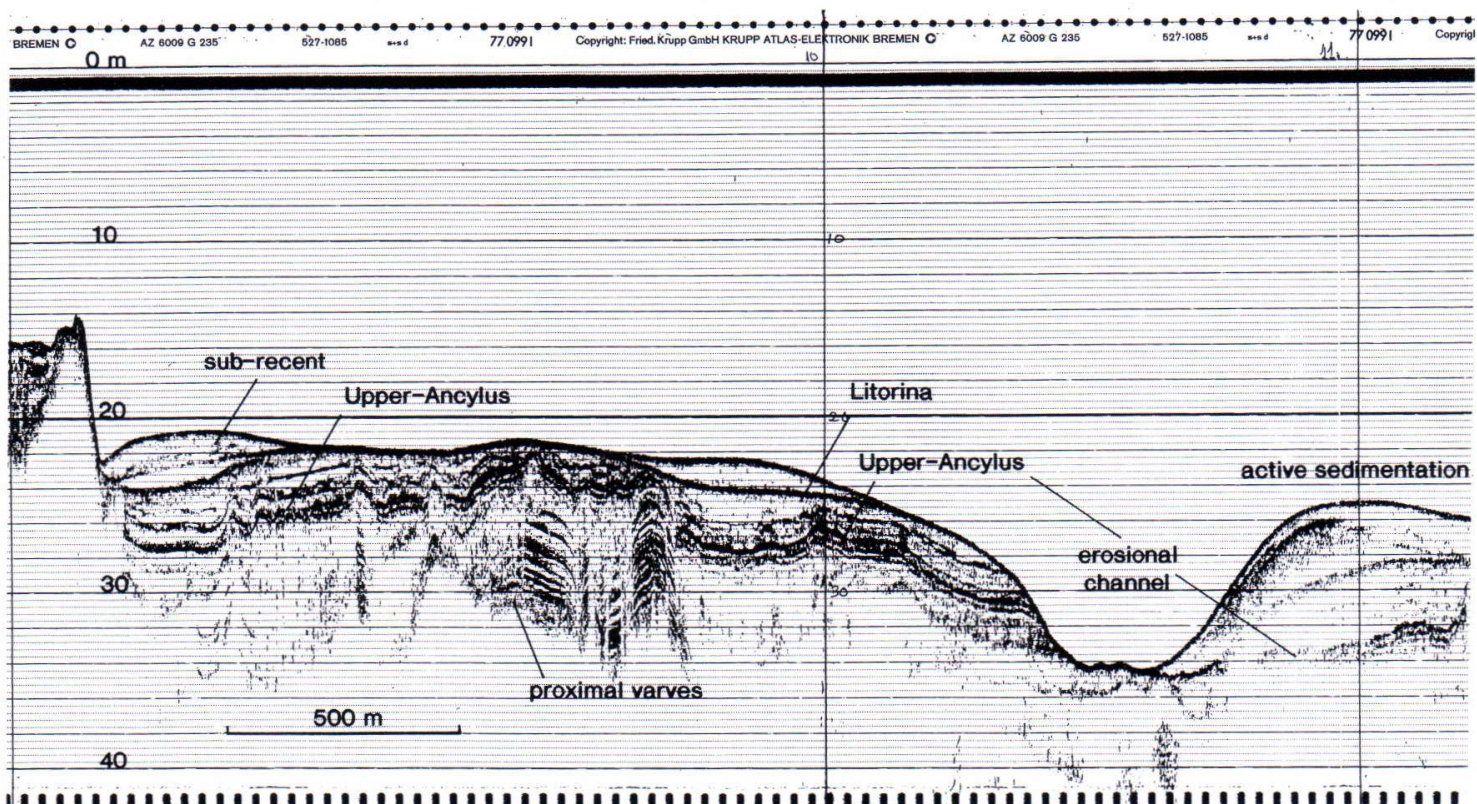

Fig. 3. Echogram from the southwestern Finnish archipelago showing the irregular Precambrian basement, the rather uniform thickness (6-7 meters) of the late-glacial silty sediments, and the acoustically persistent upper-Ancylus beds. Recent sedimentation is most active in the right hand part of the graph. The total thickness of the postglacial sediments is almost 10 meters. It should also be noted that active sedimentation occurs only along the right flank of the erosional channel.

conditions. Thus the variations in oxygen content in the bottom-near waters is clearly reflected in the deposition of either laminated or bioturbated sediments. The actual material being deposited depends on the ratio between marine organic production, including river transport of mainly humic substances, and the input of mineral matter. The latter consists of a terrigenous input and a varying amount of authigenic and above all redeposited material derived from exposed sea floors (isostatic shoaling) through wave and current erosion of formerly deposited sediments.

\section{Recent mud}

The deposition of laminated versus bioturbated gyttja clays, generally referred to as »Litorina clays» continues with little change up till the present day. Due to poor compaction, the most recent sediments (muds) do, however, often differ acoustically from underlying, more compact, sediments. This is especially true within sheltered areas, e.g. the Finnish and Swedish archipelago, where a change in current pattern, following crustal uplift (regression), has changed the bottom conditions from a temporary erosional or non-depositional environment into one of active accumulation (Fig. 3).

\section{Conclusions}

The various evolutionary phases of the Baltic Sea since the onset of the last deglaciation are well recorded in the sediments of the deep basins. The main stratigraphic units can, because of their lithological characteristics, be normally correlated across most of the area. However, there are some factors worth considering, when using seafloor sediment cores in the study of past and present environmental aspects of the Baltic Sea: 
The proximity to large rivers or wide shallow expanses of formerly deposited fine grained material, exposed through crustal uplift, can have drastically influenced the character of sediments being deposited. Thus, e.g. a large supply of varved glacial clays and silts can lead to the deposition of recent muddy sediments with the physical character of Baltic Ice Lake deposits. Only a closer scrutiny and above all the amount of organic material in the sediment can give a clue of the real state of affairs.

The fact that some of the lithological units are diachronous across the Baltic Sea (Ignatius et al. 1980) while others are clearly synchronous can lead to misunderstanding when used in conjunction with climatic chronozones. Thus, as can be

\section{References}

Eronen, M., 1988. A scrutiny of the Late Quaternary history of the Baltic Sea. In Winterhalter B. (Ed.) The Baltic Sea. Papers prepared for a colloquium on Baltic Sea Marine geology in Parainen, Finland, 27-29 May 1987. Geological Survey of Finland, Special Paper 6, 11-18.

Ignatius, H., 1958. On the Rate of Sedimentation in the Baltic Sea. Comptes Rendus de la Société géologique de Finlande 30, 135-144.

Ignatius, H., Kukkonen, E., \& Winterhalter, B. 1980. Pohjanlahden kvartäärikerrostumat. Summary: The Quaternary Deposits of the Gulf of Bothnia. Appendices: Marine geological maps of the Bothnian Sea and the Bothnian Bay, scale 1:1 000000. Geological Survey of Finland, Report of Investigations No. 45 , pp 50.

Ignatius, H., Axberg, S., Niemistö, L. \& Winterhalter, B. 1981. Quaternary Geology of the Baltic Sea. In A.Voipio (ed.) The Baltic Sea, Elsevier, Amsterdam, 54-104.

Papunen, H. 1968. On the sulfides in the sediments of the Bothnian Sea. Bulletin of the Geological Society of Finland, seen in Fig. 2 typical late glacial varved sediments were deposited in the Bothnian Bay in the Holocene i.e. "postglacial». In well aerated tracts of sea bottom, present day benthic fauna, primarily Mesidotea entomon, Pontoporeia affinis and Mysis relicta are capable of thoroughly mixing the uppermost few centimetres of material being deposited, obliterating all traces of layering which might otherwise be ascribed to annual variations in the Baltic Sea environment. We do have a general view of the stratigraphy of late Quaternary sediments of the Baltic Sea. However, much detailed works has still to be done to give us a reliable picture of the environmental conditions that have prevailed during the various phases of the Baltic Sea since the last glaciation.

No. 40 , pp $51-57$.

Söderberg, P. 1988. Notes on the continuation of the Salpausselkä ice marginal zone in the northern Baltic Proper. Geological Survey of Finland, Special Paper 6, 69-72.

Winterhalter, B. 1975. Sediment Deposition, Non-Deposition and Erosion within the Northern Baltic Sea Region. Underwater 75. Proceedings of the Forth World Congress of Underwater Activities, Stockholm 12-18 Sept 1975. Vol II, 315-322

Winterhalter, B. 1972. On the Geology of the Bothnian Sea, an Epeiric Sea that has undergone Pleistocene Glaciation. Geological Survey of Finland, Bulletin 258, 1-66.

Åker, K., Eriksson, B., Grönlund, T., and Kankainen, T. 1988. Sediment stratigraphy in the northern Gulf of Finland. In Winterhalter B. (Ed.) The Baltic Sea. Papers prepared for a colloquium on Baltic Sea Marine geology in Parainen, Finland, 27-29 May 1987. Geological Survey of Finland, Special Paper 6, 11-18.

Received August 28, 1992

Revision accepted September 22, 1992 